\title{
Heavy Metal in Dust Samples from ABA, ABIA State, Nigeria, Using Car Wind Screen as Inert Passive Collector
}

\author{
${ }^{1}$ M.N. Mgbemena and ${ }^{2}$ V.I. Onwukeme \\ ${ }^{l}$ Department Of Chemistry, Michael Okpala University Of Agriculture Umudike, Abia State, Nigeria \\ ${ }^{2}$ Department Of Pure And Industrial Chemistry, Nnamdi Azikiwe University, Awka, Nigeria.
}

\begin{abstract}
Dust samples were collected from car wind screen packed by the road sides in different locations in Aba north and South Local Government Area of Abia State, Nigeria and analyzed for heavy metals using Parkin Elma Pye Unican 400 Absorption Absorption Spectrophotometer (AAS). The results indicated the range of concentration as Chromium; $89.75 \pm 1.95$ to $114.70 \pm 4.0 \mathrm{mg} / \mathrm{kg}$ at Asa Nnetu, Lead; $297.05 \pm 2.0 \mathrm{mg} / \mathrm{kg}$ at Aba North 2 to $652.05 \pm 17.44 \mathrm{mg} / \mathrm{kg}$ at Asa Nnetu, Copper; $12.75 \pm 0.70 \mathrm{mg} / \mathrm{kg}$ to $34.75 \pm 0.75$ at Asa Nnetu, Vanadium; $73.70 \pm 3.4 \mathrm{mg} / \mathrm{kg}$ to $113.30 \pm 0.26 \mathrm{mg} / \mathrm{kg}$ in Aba South 2, Iron; $2701.50 \pm 1.5$ to $2798.33 \pm$ $2.65 \mathrm{mg} / \mathrm{kg}$ in Asa Nnetu. Manganese, (Mn); $87.30 \pm 1.5 \mathrm{in} \mathrm{Aba} \mathrm{North} 11$ to $124.50 \pm 1.32 \mathrm{mg} / \mathrm{kg}$ in Asa Nnetu. Cadmium (Cd); 8.01 .0 in Asa Nnetu to $13.50 \pm 0.50 \mathrm{mg} / \mathrm{kg}$ in Aba South 1. Statistics showed significant variation in concentrations of $\mathrm{Cu}, \mathrm{Cr}, \mathrm{Fe}, \mathrm{Mn}$ and $\mathrm{Hg}$ in the two local government areas. Similarly, the concentrations of $\mathrm{Cr}, \mathrm{Pb}, \mathrm{Cu}, \mathrm{Cd}, \mathrm{Ni}$, and $\mathrm{Hg}$ were above the Nigeria National Environmental Standards and Regulations Enforcement Agency (NESREA) soil quality for industries. The results indicated various levels of dust pollution by heavy metals in the area and so calls for concern due to the health implication of these metals.

Keywords: car window screen, heavy metals, pollution.
\end{abstract}

\section{Introduction}

Heavy metals can be ingested directly by human and animal through the inhalation of soil dust. Some heavy metals settle in dust from far distance especially from industries. Large particles that enter the respiratory system can be trapped by the hairs and linings of the nose and then driven out by sneezing or cough. Smaller particles in dust find their way into the alveoli system and can be captured by the mucus and walk back to the throat by tiny hair like cilia and get removed by swallowing or spitting. However, very small particles find their way into the lungs unhindered and depending on size get deposited there in [1]. The particles of dust from different sources have a synergic effect in atmospheric air pollution. Natural background heavy metal are sometimes difficult to distinguish from impact from human activities and in diffuse cases, it is difficult to quantify the respective contributions from each source [2].

Combustion and anthropogenic sources have been identified as the major culprits in the release of heavy metal into the atmosphere, but the later presents a more complex issue that has drawn international attention in recent years especially with regards to climate change [3]. The concentration of heavy metals in street dust decrease rapidly from area with high tropic density to semi urban and rural areas [4]. Typical lead concentration in inner city street dust range from 1000 to $10,000 \mathrm{mg} / \mathrm{kg}$, and in the rural areas, it is between 30$500 \mathrm{mg} / \mathrm{kg}$ [5]. The main heavy metals identified in urban dust include Lead $(\mathrm{Pb})$, copper $(\mathrm{Cu})$ silicon $(\mathrm{Si})$ iron $(\mathrm{Fe})$ aluminum $(\mathrm{Al})$ and cadmium $(\mathrm{Cd})$. High concentration of lead in urban house hold dust suggests that automobile emission and lead containing paint are the two major sources. Cadmium occurs in association with zinc in compounds used in rubber vulcanizing. This explains why dust from rubber tyre is a source of cadmium and zinc in street [7]. For point sources, industries commercial, metal finishing, chemical industries, mining and ore processing are the major pathways of release of heavy metals to the environment [1].

In Nigeria and indeed, other parts of West Africa, people get exposed to heavy metal by long and several contact, hours with dust and this is common from November to march. Each year however, dust emanate from complex interplay between wind and particulate matter suspended in the atmosphere. Anthropogenic dust comes from particulate matter which has been disturbed by wind or human activities such a earth moving vehicles, traffic on paved and unpaved surface [5]. The composition of dust is complex and contain organic and inorganic as well as microbial entities [6]. Ambient air dust samples from industries and residential areas of four metropolitan cities in India revealed that the concentration of elemental pollutant were highly varied and the variation was attributed to origin [1]. The study of heavy metal contamination of dust samples in Jaejon area, Korea by Kin et al revealed elevated levels of $\mathrm{Cu}, \mathrm{Pb}, \mathrm{Zn}$ in dust samples near the Tussung highway junction and industrialized area [7]. The age of the property was found to influence the levels in house dust, with older houses, ( $>15 \mathrm{yrs})$, significantly of higher concentration than never properly $(<15 \mathrm{yrs})$ [7]. Also the levels of metals in indoor dust from subway station in the city centre was $4470 \mathrm{ug} / \mathrm{g}, \mathrm{Cu}$ and $6.60 \mathrm{ug} / \mathrm{g} \mathrm{Pb}$. Nwatei and Igwebue (2009) conducted a research on the mean concentrations of metals in dust particles collected from ten 
laboratories in campus I and II of the Delta State University Abraka, Nigeria and results revealed significant variation $(\mathrm{P}<0.05)$ in metal concentration in the dust samples collected. This shows that chemicals in the laboratory are capable of contaminating the air and dust particles. The highest concentration of lead was found in physics and chemistry laboratories while elevated levels of arsenic (As), cobalt (Co) and selenium (Se) were found in dust from agricultural science laboratory. $\mathrm{Cd}$ and $\mathrm{Co}$ were found in all the laboratory studied. The study proved that chemical laboratories in Nigeria are not safe for the users because the metals investigated are found to be highly toxic when inhaled as dust or fume [8].

Metals such as lead, mercury, cadmium, arsenic nickel and aluminum cause more problem to man because they tend to accumulate in the brain, kidney and immune system where they can severely disrupt normal body function [9]. Apart from heavy metal, dust particles had been emplicated to block stomata of plant leaves, affecting adversely, photosynthesis, respiration and transpiration [3].

This work is aimed as assessing the level of airborne heavy metal by examining dust from parked vehicles on road sides in Aba metropolis, Nigeria. The information obtained will be used for mitigation strategy as well as serve as baseline for further studies in the area.

\section{The Study Area}

Aba, is a commercial nerve centre of Abia, Nigeria. It is the second largest commercial city in south east Nigeria, comprising of two local government areas, Aba south Local government area and Aba north local government area. Aba is centrally located and accessible to virtually all parts of the south south and the south east of Nigeria, $16 \mathrm{~km}$ from Uyo, the Akwa Ibom state capital, $60 \mathrm{~km}$ from Owerri, the Imo State capital, 60km from Umuahia, the Abia state capital and $60 \mathrm{~km}$ from Port-Harcourt $(\mathrm{PH})$ the river state capital. Industries are abound in Aba, ranging from textile, brewing, glass, food processing, paper mill, leather, cosmetics, drugs etc. These industries promote unrestricted population growth with the attendant increase in waste generation and as such, there is every tendency for heavy metals to contaminate the environment. Aba lies south of Umuahia at latitude $05^{0} 07^{1}$ and longitude $07^{0} 22^{1}$ on the location and position map topography sheet 321 .

\section{Collection of samples:}

\section{Materials And Methods}

The study area was divided into 5 sampling locations A,B,C,D, and E. Location A and B represent Aba south area. Location A comprise: UBN by force road, Aba town hall and Osusu areas. Local B, comprise Umungasi, Umuele by Okigwe road and Ariaria. Location C, comprise Abia-line, Brass junction and National High School road. Location D, comprise: Umumbai by Ngwa road, Ihiorji village road and Umuogele, while location E, comprise Asa nnentu, PH express and the surroundings. Ramdom samples of dust were collected at 4 different points in each area of the location and pooled to obtain a composite sample. Three areas were mapped out from each location for collection of three composite samples, one from each area. The dust samples were collected with a plastic brush from the window screens of packed vehicles within the selected areas. The composite dust samples were stored in a clean labelled plastic bags and taken to the laboratory for analysis.

\section{Digestion of dust samples:}

$1.0 \mathrm{~g}$ of each dust sample was weighed into different $50 \mathrm{~cm}^{3}$ beaker to which $10 \mathrm{~cm}^{3}$ of nitric acid $\left(\mathrm{HNO}_{3}\right)$ was carefully added. It was heated to partial dryness on a digestion block inside the fume cupboard. The beakers were allowed to cool and $10 \mathrm{~cm}^{3}$ of perchloric acid was carefully added to each sample and heated carefully to dryness. The digested samples were cooled and $20 \mathrm{~cm}^{3}$ of water was added, stirred filtered into a $50 \mathrm{~cm}^{3}$ volumetric flask and made up to the mark with distilled water. Heavy metal content of the samples was determined using AAS Atomic Absorption Spectrometer Parkin Elmer Instrument model 400 Pye Unican,

\section{Data Analysis}

Results were expressed a mean with standard deviation and t-test was used for analysis of variation of heavy metals between the two local government areas at $\mathrm{p}<0.05$.

\section{Results And Discussion}

The results of this analysis are presented in Table 1 (A and B) 


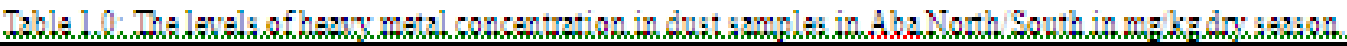

\begin{tabular}{|c|c|c|c|c|c|c|c|c|c|c|c|c|}
\hline $\begin{array}{l}\text { Locati } \\
\text { on } n z \\
\text { ma }\end{array}$ & Chromiz & \begin{tabular}{l|l}
$\mathrm{m}$ & $\mathrm{L}=2 \mathrm{~d}$
\end{tabular} & Copps & Cobal & $\begin{array}{l}\text { Venadi } \\
\text { um }\end{array}$ & Iron & Nengan & $\begin{array}{l}\text { Cadm } \\
\text { ium }\end{array}$ & $\begin{array}{l}\text { Nick } \\
\text { al }\end{array}$ & Zinc & $\begin{array}{l}\text { Merc } \\
\text { ury }\end{array}$ & $\begin{array}{l}\text { Arsen } \\
\text { ic }\end{array}$ \\
\hline$A$ & $A b 2$ Nor & $\operatorname{th} I G A$ & & & & & & & & & & \\
\hline$D A_{1}$ & $\begin{array}{l}945= \\
250\end{array}$ & $\begin{array}{l}592.50= \\
22.5\end{array}$ & $\begin{array}{l}15.30 \\
= \\
1.18\end{array}$ & $\begin{array}{l}13.50 \\
= \\
1.80\end{array}$ & $\begin{array}{l}97.10 \\
= \\
1.10\end{array}$ & $\begin{array}{l}2701.50 \\
= \\
1.50\end{array}$ & $\begin{array}{l}117.55 \\
= \\
1.36\end{array}$ & $\begin{array}{l}8.50 \\
= \\
1.32\end{array}$ & $\begin{array}{l}70.0 \\
0= \\
1.32\end{array}$ & $\begin{array}{l}160.4 \\
5 \pm \\
1.32\end{array}$ & $\begin{array}{l}0.517 \\
= \\
0.10\end{array}$ & $\begin{array}{l}0.00 \\
= \\
00\end{array}$ \\
\hline$\overline{\mathrm{DB}}:$ & $\begin{array}{l}89.75= \\
195\end{array}$ & $\begin{array}{l}297.70= \\
24.60\end{array}$ & $\begin{array}{l}12.75 \\
=0.75\end{array}$ & $\begin{array}{l}10.60 \\
= \\
0.45\end{array}$ & $\begin{array}{l}73.70 \\
=3.40\end{array}$ & $\begin{array}{l}98.0= \\
1.00\end{array}$ & $\begin{array}{l}87.50= \\
1.52\end{array}$ & $\begin{array}{l}9.00 \\
= \\
0.50\end{array}$ & $\begin{array}{l}75.0 \\
0= \\
3.27\end{array}$ & $\begin{array}{l}1603 \\
0= \\
390\end{array}$ & $\begin{array}{l}0.50 \\
=1.0\end{array}$ & $\begin{array}{l}0.00 \\
=00\end{array}$ \\
\hline Matn & $\begin{array}{l}92.30 \\
=3.18\end{array}$ & $\begin{array}{l}445.10= \\
33.39\end{array}$ & $\begin{array}{l}1402 \\
=1.39\end{array}$ & $\begin{array}{l}12.05 \\
= \\
1.85\end{array}$ & $\begin{array}{l}85.35 \\
=3.37\end{array}$ & $\begin{array}{l}2745.25 \\
=1.80\end{array}$ & $\begin{array}{l}10253 \\
=1.89\end{array}$ & $\begin{array}{l}8.27 \\
= \\
1.41\end{array}$ & $\begin{array}{l}72.5 \\
0= \\
3.52\end{array}$ & $\begin{array}{l}1603 \\
8= \\
411\end{array}$ & $\begin{array}{l}0.51 \\
=1.0\end{array}$ & $\begin{array}{l}0.00 \\
= \\
0.00\end{array}$ \\
\hline $\begin{array}{l}\text { Varian } \\
\text { Ca }\end{array}$ & 10.11 & 111489 & 193 & 3.42 & 12.74 & 324 & 3.57 & 198 & $9_{9}^{123}$ & 16.89 & 1.00 & 0.00 \\
\hline $\mathrm{CV} \%$ & 3.4 & 75 & 991 & 1535 & 4.18 & 0.0007 & 1.84 & 1.74 & 48 & 6.18 & 200 & 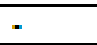 \\
\hline$B$ & $A b=$ Sou & th Ares L G & & & & & & & & & & \\
\hline $\mathrm{DC}_{1}$ & $\begin{array}{l}96.50 \\
=2.5\end{array}$ & $\begin{array}{l}480.60= \\
0.95\end{array}$ & $\begin{array}{l}1920 \\
=0.95\end{array}$ & $\begin{array}{l}15.40 \\
= \\
1.25\end{array}$ & $\begin{array}{l}80.50 \\
=1.80\end{array}$ & $\begin{array}{l}2760000 \\
=5290\end{array}$ & $\begin{array}{l}90.55= \\
1.53\end{array}$ & $\begin{array}{l}8.0 \pm \\
1.00\end{array}$ & $\begin{array}{l}90.0 \\
5= \\
2.08\end{array}$ & $\begin{array}{l}160.0 \\
0= \\
3.61\end{array}$ & $\begin{array}{l}20.15 \\
= \\
0.15\end{array}$ & 0.00 \\
\hline$\overline{\mathrm{DD}}:$ & $\begin{array}{l}96.05 \\
=1.05\end{array}$ & $\begin{array}{l}35800= \\
200\end{array}$ & $\begin{array}{l}15.40 \\
=0.40\end{array}$ & $\begin{array}{l}29.50 \\
= \\
0.45\end{array}$ & $\begin{array}{l}11330 \\
=0.26\end{array}$ & $\begin{array}{l}2790.00 \\
=5.0\end{array}$ & $\begin{array}{l}118.00 \\
=1.8\end{array}$ & $\begin{array}{l}13.50 \\
= \\
0.50\end{array}$ & $\begin{array}{l}350 \\
0= \\
20\end{array}$ & $\begin{array}{l}160.2 \\
0= \\
1.73\end{array}$ & $\begin{array}{l}36.70 \\
= \\
0.90\end{array}$ & 0.00 \\
\hline$\overline{D E}$ & $\begin{array}{l}144.70 \\
=40\end{array}$ & $\begin{array}{l}652.05= \\
17.44\end{array}$ & $\begin{array}{l}72.80 \\
=2.0\end{array}$ & $\begin{array}{l}34.75 \\
= \\
0.75\end{array}$ & $\begin{array}{l}102.40 \\
=7.22\end{array}$ & $\begin{array}{l}2798.00 \\
=2.65\end{array}$ & $\begin{array}{l}12450 \\
=1.00\end{array}$ & $\begin{array}{l}8.50 \\
= \\
0.43\end{array}$ & $\begin{array}{l}125 \\
00= \\
5.0\end{array}$ & $\begin{array}{l}1610 \\
0= \\
1.82\end{array}$ & $\begin{array}{l}33.05 \\
= \\
0.05\end{array}$ & $\begin{array}{l}0.00 \\
= \\
0.00\end{array}$ \\
\hline Man & $\begin{array}{l}112.41 \\
=483\end{array}$ & $\begin{array}{l}487.21= \\
26.72\end{array}$ & $\begin{array}{l}35.93 \\
=225\end{array}$ & $\begin{array}{l}26.0 \\
= \\
1.52\end{array}$ & $\begin{array}{l}98.73 \\
=3.25\end{array}$ & $\begin{array}{l}2782.66 \\
=5.72\end{array}$ & $\begin{array}{l}111.18 \\
=2.79\end{array}$ & $\begin{array}{l}10.00 \\
= \\
1.19\end{array}$ & $\begin{array}{l}833 \\
5= \\
5.77\end{array}$ & $\begin{array}{l}160.4 \\
0= \\
438\end{array}$ & $\begin{array}{l}29.96 \\
= \\
0.91\end{array}$ & 0.00 \\
\hline $\begin{array}{l}\cdot c 2] \\
4=2.1 \\
3 \\
\end{array}$ & $2.6^{4}$ & 1.02 & $8.79^{\circ}$ & $6.63^{\circ}$ & $3.05^{\circ}$ & $6.85^{\circ}$ & $282^{\circ}$ & 0.74 & 1.76 & 9994 & 2395 & \\
\hline $\begin{array}{l}\text { Verizm } \\
\text { ca }\end{array}$ & 2332 & 71395 & 5.06 & 231 & 10.49 & 32.71 & 7.78 & 1.41 & $\begin{array}{l}332 \\
9\end{array}$ & 19.18 & 0.83 & 0.00 \\
\hline $\mathrm{CV} \%$ & 42 & 5.4 & 62 & 5.7 & 32 & 2.05 & 2.5 & 19 & 69 & 2.7 & 30 & 0.0 \\
\hline $\begin{array}{l}\text { NESR } \\
\text { EA } \\
\text { STD } \\
m z k z\end{array}$ & 100 & 10 & 100 & 50 & $\cdot$ & $\cdot$ & - & 3.0 & 70 & 421 & 40 & 20 \\
\hline
\end{tabular}

Key: ${ }^{2} \mathrm{DA}_{1}$ : Dust from Aba North 1

$\mathrm{DB}_{2}$ : Dust from Aba North 2

$\mathrm{DC}_{1}$ : Dust from Aba South 1

$\mathrm{DC}_{2}$ : Dust from Aba South 2

DE: Dust from Aba Nnetu

$\mathrm{t}$ value marked $*$ are significant

Chromium concentration varied from $89.75 \pm 1.95$ to $144.70 \pm 4.0 \mathrm{mg} / \mathrm{kg}$ at Aba North 2 and Asa Nnetu respectively lead concentration varied from $297.00 \pm 2.0$ to $652.05 \pm 17.44 \mathrm{mg} / \mathrm{kg}$ at Aba north 11 and Asa Nnetu respectively. Also, copper concentration followed the same trend from $12.75 \pm 0.75 \mathrm{mg} / \mathrm{kg}$ to $34.75 \pm$ 0.12 at Aba-north and Asa-Nnetu respectively. Similarly vanadium concentration varied from $73.70 \pm 3.40$ $\mathrm{mg} / \mathrm{kg}$ to $113.36 \pm 0.26 \mathrm{mg} / \mathrm{kg}$ in Aba north 2 and Aba south 2 respectively. Iron concentration varied from $2701.50 \pm 1.5 \mathrm{mg} / \mathrm{kg}$ in Aba north 1 to $2798.33 \pm 2.65 \mathrm{mg} / \mathrm{kg}$ in Asa Nnetu. The concentrations of manganese, cadmium nickel, zinc and mercury varied from $87.50 \pm 1.32 \mathrm{mg} / \mathrm{kg}$ in Aba north 2 to $124.50 \pm 1.5 \mathrm{mg} / \mathrm{kg}$ in Asa Nnetu, $8.0 \pm 1.0 \mathrm{mg} / \mathrm{kg}$ in Aba south 1 to $13.50 \pm 0.50 \mathrm{mg} / \mathrm{kg}$ in Aba south, $35.00 \pm 2.0 \mathrm{mg} / \mathrm{kg}$ to Aba south 2 to $125.00 \pm 5.0 \mathrm{mg} / \mathrm{kg}$ in Asa Nnetu, $160.00 \pm 1.80 \mathrm{mg} / \mathrm{kg}$ to $161.00 \pm 1.80 \mathrm{mg} / \mathrm{kg}$ in Asa Nnetu, $0.50 \pm 0.10$ $\mathrm{mg} / \mathrm{kg}$ in Aba south 2 to $36.70 \pm 0.9 \mathrm{mg} / \mathrm{kg}$ in Aba south 2. No Arsenic was detected in the dust samples studied. Almost all the metals had elevated level at Asa Nnetu, the mechanic village. This may be attributed to 
emission and anthropogenic activities in the area especially cars, abrasion of rubber tyres and mechanical abrasion. It was reported that cadmium occurs in rubber tyre because of its chemical and mineralogical association with zinc (Sartorius et al (1977), added during vulcanization of rubber. This may be the reason why dust from rubber tyres is the main source of cadmium in street dust [4].

The concentration of $\mathrm{Zn}, \mathrm{Pb}, \mathrm{Co}, \mathrm{Cd}$ and $\mathrm{Hg}$ are not significantly affected by location of $\mathrm{p}>0.05$. Most of the locations studied had equal concentration of zinc. This suggests that the level of zinc in the environment might mainly be from a common source. Even- though zinc is an essential metal, high concentration is dangerous, especially where it is known that zinc has additive toxicity with metals such as lead and mercury also found in appreciable level in the environment. These concentrations portend level of pollution of the area. Also, fertilizer, motor tyres, batteries motor oil, fungi-cides, plastics and coal which have been implicated as the main source of cadmium are common in the area. Cadmium inhibites enzymes and has affinity to important ligands/nutrient in the living cells. It interactions with $\mathrm{Cu} F e$ and $\mathrm{Zn}$ in the body induce deficiency symptoms such as hypertension, respiratory disorder, damage to kidney and liver, formation of kidney stone, irritability pneumonities and broncho pneumonia [2].

The mean concentration of these metals was high in Asa Nnetu, followed by Aba north 2 and then Aba south 2. The high level of metals in Aba south 2 may be due to small mechanic village situated in that areas. Aba South 1 and Aba North had low concentration of heavy metals compared to other area. The low concentration of heavy metal in street dust from Aba north 2 may be due to the fact that the area was less busy and with less traffic. This indicates that traffic is a good source of heavy metal emission. The concentrations of heavy metals in street dust decreased rapidly from area of high density to that of mid density and finally lead busy area as was observed by Fergusson et al (1990). High concentration of $\mathrm{Fe}, \mathrm{Pb}, \mathrm{Cd}$, and $\mathrm{Zn}$ were observed the dust. Then followed a similar trend as was observed by Kim et al (1998) and Fergusson et al (1990).

The high concentration of lead in urban dust suggests that automobile emissions and lead containing paint are the main sources of these metlas, especially at Asa Nnetu at $652.05 \pm 17.44 \mathrm{mg} / \mathrm{kg}$. High lead level had been reported to cause neuro-psychological, cardiovascular, morphological changes and gastro intestinal disturbances in human [12].

$\mathrm{T}$ statistics shows that there is a significant difference in the concentration of $\mathrm{Cu}, \mathrm{Cr}, \mathrm{Fe}, \mathrm{Mn}$ and $\mathrm{Hg}$ in the two local government area in Aba metropolis at $\mathrm{P}>0.05$. Even at this, the concentrations of $\mathrm{Pb}, \mathrm{Cr}$, and $\mathrm{Ni}$, were well above the Nigerian National Environmental Standards and Regulations Enforcement Agency 2009 (NESREA) soil quality for industries in both local government areas that make up Aba metropolis.

Mercury concentration was well below the standard at all sites in Aba north area but not for all sites in Aba south area. The high level of mercury in Aba south area may be attributed to the geology of the area, since volcanic eruption has been identified to contribute more mercury into the environment then from human activity [14]. This calls for concern as repeated and prolong exposure to mercury has severe consequences in the central nervous system, kidney and liver. Mercury breaks barriers in the capillaries, resulting to oedema, and other neurological effects such as hyper-reflexia and trema (oral Chelation 2005).

\section{References}

[1] G.M. Masters (1998); Introduction to environmental engineering and science and $2^{\text {nd }}$ edition, prentice Hill Ltd London pp $327-451$

[2] UNEP (1999); United Nations environmental programme.

[3] C.M.A Ademosoti (1986) Environmental chemistry and Toxicology, Foludex Press Ltd Ltd Ibadan pp 30-31.

[4] J.E. Fergussion (1990); The heavy element chemistry environmental impact and health effect Fergamon press Oxford p 850.

[5] G.A. Dimari S.S. Hati, M. Waziri and O.N. Maitera (2008), Pollution synergy from particulate matter sources: The Harmattan Fugitive dust and combustion emission in Maduguri Metroplis Nigeria. European Journal of Scientific Research 23(3): 465-471.

[6] USEPA (1999) U environmental protection agency. Washington DC.

[7] K.W. Kim, J.H. Myung, J.S. Ahu and H.J. Chon (1998). Heavy metal contamination in dust and stream sediment in the Joejon area Korea. Journal of Geochemical exploration, 64: 409-414.

[8] G.E. Nwajei and C.M.A Igwebue (2007) Heavy metal in dust particles from selected laboratories in delta state University Abraka Nigeria, Journal Chemical society of Nigeria 32(2): 287-291.

[9] B.C Gerstner and J.E. Huff (1997); Clinical technology of mercury J,. Toxicol Environ. Health 2: 167-171.

[10] J.R. Nation, M.F. Have and D.M. Baker (2005). Dictary Administration of Nickel, Effect on behavior and Melatothiane levels. Physiol Behavious 34: 349-533.

[11] Sartoris, R. Seifert and F. Vajvenhoff (1977). Emission asquellen and immision situation for cadmium, Index Burdes republic deatschland staub. Ranhelt, Luft 37:422-426.

[12] S.S. Dara (2004); Envirnmental chemistry $8^{\text {th }}$ edn. S Chart and company Ltd New Delhi pp 202-204.

[13] NRSREA, Nigerian National Environmental standards and regulations Enforcement Agency, Federal Republic of Nigeria SS 332009.

[14] J.W. Hill (1980). Chemistry for changing times $3^{\text {rd }}$ edn Burgress publishing company New York PP 258-366.

[15] Oral Chellation (2005) Oral chellation for heavy metal detoxification, extreme health US Inc P. 16. 